\title{
T-2 MYCOTOXIN SLOWS DOWN THE DEVELOPMENT OF MOUSE BLASTOCYSTS, DECREASES THEIR BLASTOMERE NUMBER AND INCREASES CHROMATIN DAMAGE
}

\author{
Bence SOMOSKÖI ${ }^{1 *}$, Melinda KovÁCS ${ }^{2}$ and Sándor $\mathrm{CSEH}^{1}$ \\ ${ }^{1}$ Department and Clinic of Reproduction, University of Veterinary Medicine, István u. 2, \\ H-1078 Budapest, Hungary; ${ }^{2}$ MTA-KE Mycotoxins in the Food Chain Research Group, \\ Kaposvár, Hungary
}

(Received 22 February 2016; accepted 4 May 2016)

\begin{abstract}
The mycotoxin T-2 has many harmful effects on mammalian cells and reproductive functions. In the present study, the in vitro effect of T-2 toxin on mouse blastocysts was examined. Embryos were cultured in media supplemented with $0.5,0.75$ and $1 \mathrm{ng} / \mathrm{ml} \mathrm{T-2}$. Different exposure times were applied [96 h (treatment I) or $24 \mathrm{~h}$ following $72 \mathrm{~h}$ in toxin-free media (treatment II)]. Blastomere number, nuclear chromatin status and blastocoel formation were investigated in blastocysts. Our data show that the effect of T-2 toxin may vary depending on the stage of the embryo at the start of exposure. At $96 \mathrm{~h}$ of exposure, the blastocysts had blastomeres with normal chromatin quality but their developmental potential was decreased. After $24 \mathrm{~h}$ of exposure applied following a 72-h culture, blastomeres had a higher level of chromatin damage, although their developmental potential was the same as in the control embryos. In both cases, decreased mitotic rate was found, which resulted in decreased blastomere number even at low toxin concentration.
\end{abstract}

Key words: $\mathrm{T}-2$ toxin, embryotoxicity, nuclear chromatin, mouse embryos, blastocoel, in vitro culture

T-2 toxin (T-2) is a type A trichothecene mycotoxin produced by phytopathogenic fungi of the Fusarium genus, mainly by $F$. sporotrichoides and $F$. poae, which can infect crop plants such as wheat, barley, oat and rice in temperate climates (Glenn, 2007). In Europe, especially in the Nordic countries, the contamination of cereals with T-2 and HT-2 toxins is also a serious problem (Beyer et al., 2009). According to the latest mycotoxin survey report from 2015 (Biomin Holding GmbH, 2015), 57\% of feed samples were contaminated with T-2 in Central Europe. T-2 toxin, which has the highest toxicity among trichothecenes, may cause gastrointestinal, dermatological, immunological and neurologic symptoms in experimental and farm animals (Bennett and Klich, 2003). Recently, it

*Corresponding author; E-mail: somoskoi.bence@univet.hu; Phone: 0036 (70) 424-6730 
has been reported that T-2 toxin enters the brain via the blood-brain barrier (Weidner et al., 2013).

Besides the well-documented harmful effects of T-2, many studies in animals have revealed that T-2 can cause reproductive disorders in both males and females. These abnormalities include retarded ovulation and decreased progesterone production (Huszenicza et al., 2000), disrupted corpus luteum maturation (Ványi et al., 1995), inhibited granulosa cell proliferation (Caloni et al., 2009), as well as reduced sperm motility and testosterone production (Kovács et al., 2011).

Although wide-scale studies about T-2 are available, effects of the toxin on early embryo development have not been revealed to date. A recent study conducted by our group showed that T-2 can cause developmental arrest in mouse embryos and can delay their development by $24 \mathrm{~h}$, resulting in late formation of the blastocoel (Somosköi et al., 2014). The aim of this study was to assess the effect of T-2 on preimplantation mouse embryos being in the morula and blastocyst stage (following 72 and $96 \mathrm{~h}$ of culture in a medium supplemented with the toxin at different concentrations) and having normal morphology.

\section{Materials and methods}

\section{Animal housing and mating}

Procedures with animals were performed following good veterinary practice for animal welfare according to the Hungarian national laws in force. The protocol of the animal experiment was approved by the Food Chain Safety and Animal Health Directorate of Pest County's Government Office (11/1/2015). Six weeks old BDF1 (National Institute of Oncology, Budapest, Hungary) mice were kept under a 12 hours light/12 hours dark schedule at a temperature of $21^{\circ} \mathrm{C}$. Feed and drinking water were available ad libitum. Superovulated [Day 1: $7.5 \mathrm{IU}$ eCG ip.; Day 3: 7.5 IU hCG ip. (Alvetra und Werfft, Austria)] female mice were placed together overnight with mature males after hCG treatment.

\section{Embryo culture and treatment}

One-cell zygotes were obtained from females sacrificed by cervical dislocation $20 \mathrm{~h}$ after hCG treatment, pooled and transferred randomly to culture medium (Cleavage Medium, Cook Medical, Roskilde, Denmark). Embryos were exposed to T-2 toxin (Sigma, St. Louis, Missouri, USA) in the following structure:

Treatment I: embryos were cultured in vitro for $96 \mathrm{~h}$ in culture media supplemented with T-2 at different concentrations $(0.5 \mathrm{ng} / \mathrm{ml}, 0.75 \mathrm{ng} / \mathrm{ml}$ and $1.0 \mathrm{ng} / \mathrm{ml})$.

Treatment II: to investigate the stress tolerance against the toxin in compacted stages, embryos were cultured in vitro in a medium with no toxin for 
$72 \mathrm{~h}$, and then morphologically normal embryos were transferred into culture media contaminated with $0.5 \mathrm{ng} / \mathrm{ml}, 0.75 \mathrm{ng} / \mathrm{ml}$ and $1.0 \mathrm{ng} / \mathrm{ml}$ toxin (group names: $\operatorname{Tr} 05, \operatorname{Tr} 075$ and $\operatorname{Tr} 1$, respectively).

Toxin concentrations were based on our previous studies (Somosköi et al., 2012 , 2014). Embryos cultured in a medium with no toxin were regarded as the control group. All embryos were cultured at $37.5^{\circ} \mathrm{C}$ with $6.5 \% \mathrm{CO}_{2}$ and maximal humidity in air. Average embryo number was 20.6/group/repeat. The experiment was performed in three repeats, with 5 animals/repeat $(n=15)$.

Embryos were stained with SYBR14 (Life Technologies, USA) and propidium iodide (PI) (Life Technologies, USA) at 72 and $96 \mathrm{~h}$ of culture to assess the cell number of embryos, dead (necrotic) cells and the proportion of blastomeres with damaged nuclear chromatin (micronuclei). Staining and comparison were performed only in the case of morphologically normal embryos in each group.

Blastocysts were investigated using an Olympus CKX41 invert microscope and Olympus E-330 digital camera system. Pictures were taken at the 96th h of culture and embryos were classified based on the expansion of blastocoel [early and mid-, expanded and hatched blastocysts (Saiz and Plusa, 2013)].

\section{Statistical analysis}

Data were analysed with $\mathrm{R}$ v3.0.0 software. ANOVA with post-hoc Tukey's test was used for comparing the mean cell number between groups. Differences in blastocoel expansion of blastocysts were measured with chi-squared test. Differences at a probability value $(\mathrm{P})$ of $<0.05$ were considered significant.

\section{Results}

\section{Cell number of embryos following $72 \mathrm{~h}$ of culture}

Cell numbers of embryos in treatment I $(0.5 \mathrm{ng} / \mathrm{ml}: 20 \pm 7.22 ; 0.75 \mathrm{ng} / \mathrm{ml}$ : $18.77 \pm 5.52 ; 1 \mathrm{ng} / \mathrm{ml}: 13.11 \pm 7.35)$ were significantly lower $(\mathrm{P}<0.001)$ than in the control embryos $(27.74 \pm 7.35)$ (Fig. 1). Significant differences between the highest toxin contamination $(1 \mathrm{ng} / \mathrm{ml})$ and lower toxin concentrations were found $(\mathrm{P}=0.046$ to $0.75 \mathrm{ng} / \mathrm{ml}$ and $\mathrm{P}=0.01$ to $0.5 \mathrm{ng} / \mathrm{ml})$. There was no difference in the cell numbers of embryos between the groups treated with $0.5 \mathrm{ng} / \mathrm{ml}$ and $0.75 \mathrm{ng} / \mathrm{ml} \mathrm{T}-2$ toxin. The proportion of PI-positive cells was under $1 \%$ in the treated and control groups (data not shown). 


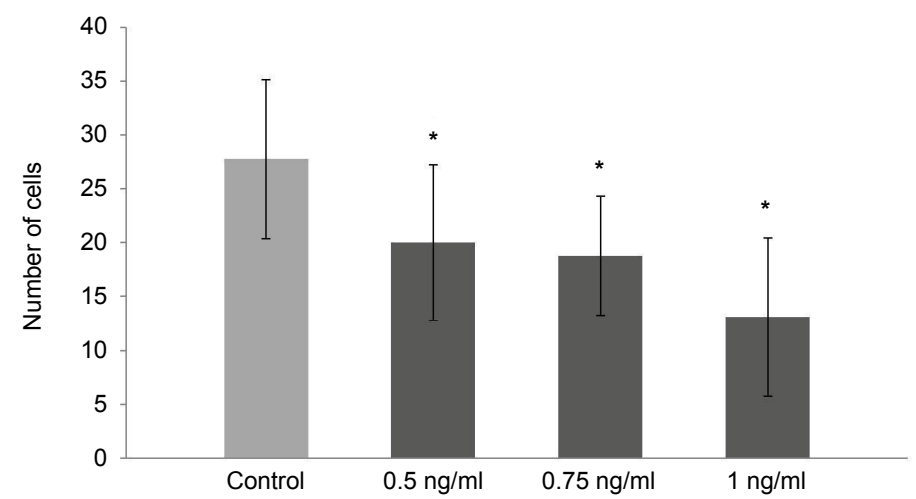

Fig. 1. Number of cells (mean $\pm \mathrm{SD}$ ) in mouse embryos treated with $0.5 \mathrm{ng} / \mathrm{ml}, 0.75 \mathrm{ng} / \mathrm{ml}$ and $1 \mathrm{ng} / \mathrm{ml} \mathrm{T}-2$ after $72 \mathrm{~h}$. Control embryos were cultured in a medium without toxin. P $<0.001$, Tukey's test

\section{Cell number of embryos following 96 h of culture}

The mean cell number of control embryos was $91.52( \pm 26.09)$ after $96 \mathrm{~h}$ of in vitro culture. Every treated group showed a significant difference compared to the control group $(0.5 \mathrm{ng} / \mathrm{ml}: 46.33 \pm 19.1 ; 0.75 \mathrm{ng} / \mathrm{ml}: 57.93 \pm 24.7 ; 1 \mathrm{ng} / \mathrm{ml}$ : $27.77 \pm 12.07$ ) (Fig. 2A) in respect of cell number. A difference was found in cell number between the groups treated with $1 \mathrm{ng} / \mathrm{ml}$ and $0.75 \mathrm{ng} / \mathrm{ml}$ toxin $(\mathrm{P}<$ 0.001 ), but no difference was observed between groups treated with $0.5 \mathrm{ng} / \mathrm{ml}$ and $0.75 \mathrm{ng} / \mathrm{ml}$ toxin concentrations.

The cell number of embryos in treatment II was significantly lower than that of the control embryos $(54.86 \pm 22.51$ in $\operatorname{Tr} 05,67.66 \pm 26.76$ in $\operatorname{Tr} 075$ and $54.73 \pm 38.66$ in $\operatorname{Tr} 1)$. However, no differences were found between the $\operatorname{Tr} 05$, $\operatorname{Tr} 075$ and $\operatorname{Tr} 1$ groups (Fig. 2B). A significant difference between treatments I and II was observed only in the case of $1 \mathrm{ng} / \mathrm{ml} \mathrm{T}-2$ concentration $(\mathrm{P}=0.048)$ (Fig. 2C).

The mean proportion of PI-positive cells was under $1.5 \%$ in all treated and control embryos (the highest rate was $8.82 \%$ in the $1 \mathrm{ng} / \mathrm{ml}$ group, but the upper quartile was under $2 \%$ in all of the treated, transferred and control embryos; data not shown).

A representative image of cell staining is shown in Fig. 3.

\section{Chromatin damage (micronuclei)}

The proportion of blastomeres with chromatin damage was $6.15 \%( \pm 2.91)$ in the control group, and $7.68 \%( \pm 4.67)$ in the $0.5 \mathrm{ng} / \mathrm{ml}, 7.46 \%( \pm 5.57)$ in the $0.75 \mathrm{ng} / \mathrm{ml}, 7.69 \%( \pm 4.21)$ in the $1 \mathrm{ng} / \mathrm{ml}, 19.37 \%( \pm 7.92)$ in the $\operatorname{Tr} 05,12.86 \%$ $( \pm 6.09)$ in the $\operatorname{Tr} 075$ and $8.96 \%( \pm 5.68)$ in the $\operatorname{Tr} 1$ groups. Embryos in the $\operatorname{Tr} 05$ and $\operatorname{Tr} 075$ groups contained micronuclei in significantly higher $(\mathrm{P}<0.001$ and 
$\mathrm{P}<0.01)$ proportion compared to the control. Transfer of embryos into toxincontaminated media resulted in a significantly higher rate of micronuclei in the $0.5 \mathrm{ng} / \mathrm{ml}(\mathrm{P}<0.001)$ and $0.75 \mathrm{ng} / \mathrm{ml}(\mathrm{P}<0.05)$ treatment groups (Fig. 4). No effect was found after culturing in a medium with $1 \mathrm{ng} / \mathrm{ml}$ toxin for 96 or $24 \mathrm{~h}$.
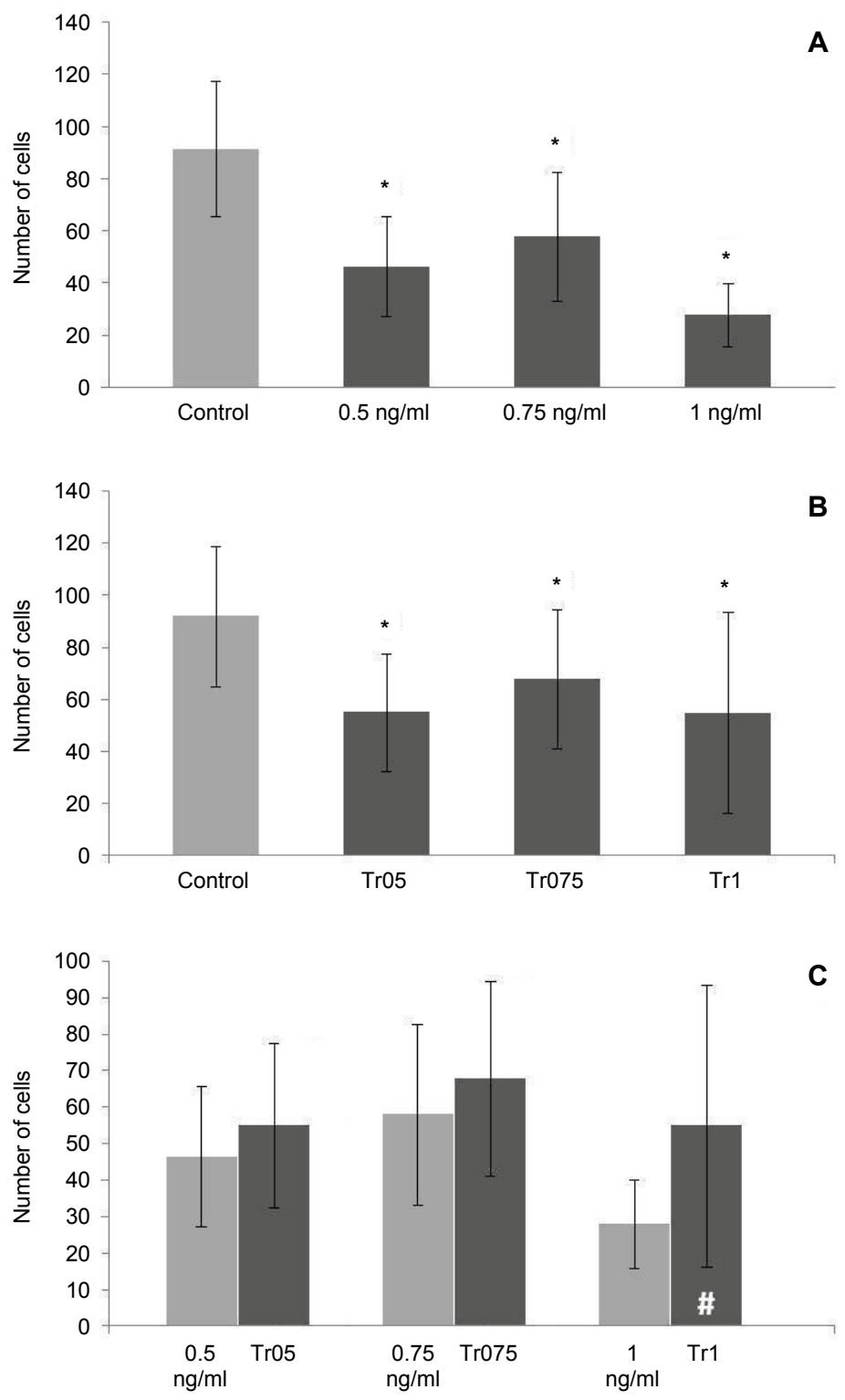

Fig. 2. Comparison of cell number (mean $\pm \mathrm{SD}$ ) in embryos of control and treatment I (A), control and treatment II (B) groups and in toxin-treated embryos (C) at the 96th $\mathrm{h}$ of culture.

${ }^{*}$ Significant difference from control embryos; ${ }^{~} \mathrm{P}<0.05$ within toxin treatments 


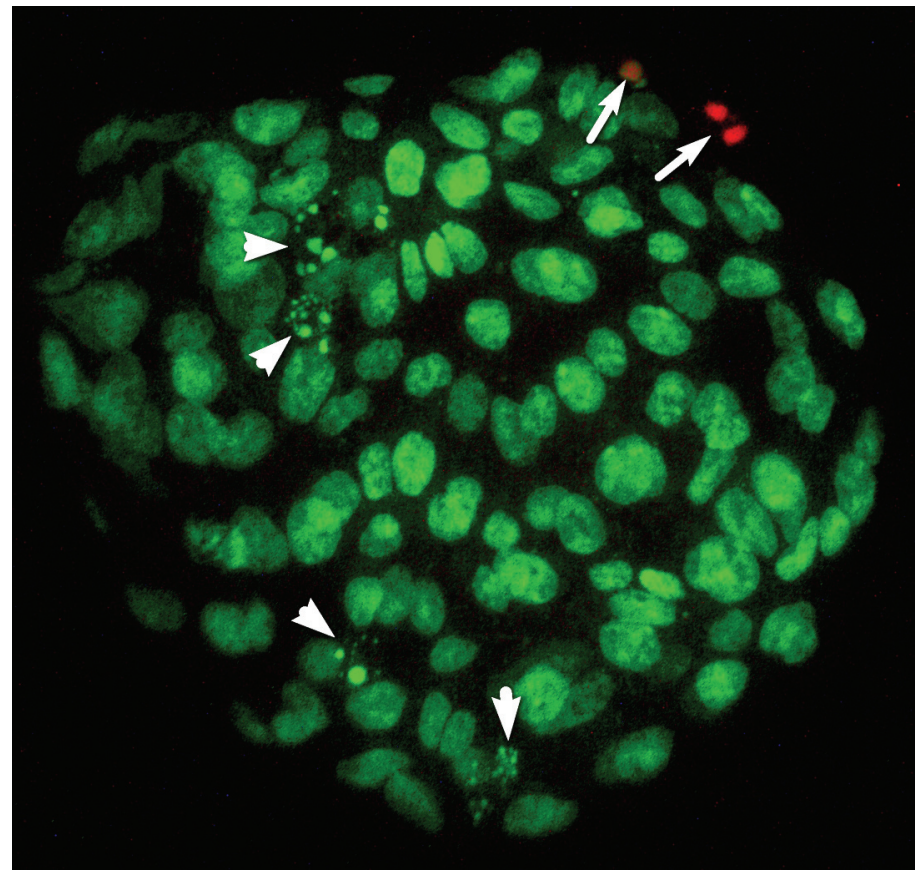

Fig. 3. Representative image of a blastocyst (treated with $0.75 \mathrm{ng} / \mathrm{ml} \mathrm{T}-2$ ) stained at the 96 th hour of in vitro culture with SYBR14 and propidium iodide. Arrows show PI-positive nuclei and arrowheads show micronuclei (chromatin damage)

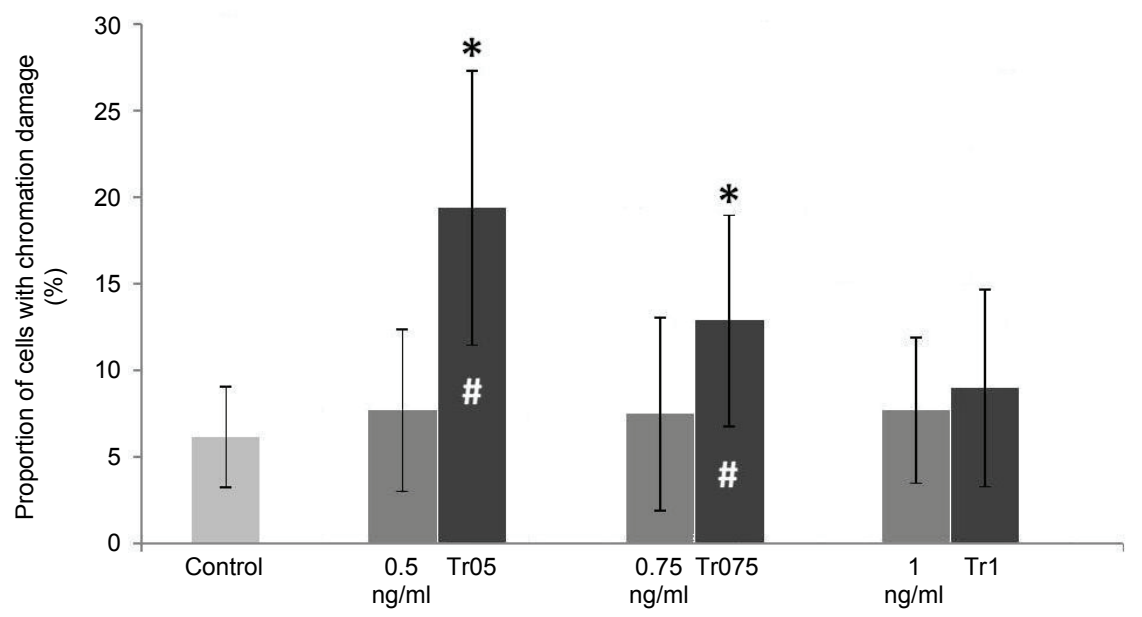

Fig. 4. Proportion of cells (mean \pm SD) with chromatin damage in embryos of the control, treatment I and treatment II groups. ${ }^{*}$ Significant difference from control embryos; ${ }^{*}$ significant difference within treatments 


\section{Blastocoel expansion}

The proportion of different blastocyst types (early and mid-, expanded and hatched; Fig. 5) following $96 \mathrm{~h}$ of culture in each group is shown in Fig. 6. A dose-dependent, significantly decreased rate of expanded/hatched blastocysts was found in the groups of treatment I $(67.9,58.6$ and 55\%) compared to the control $(87.7 \%)$. No difference was found in blastocoel expansion between the control and the toxin-contaminated embryos in treatment II.
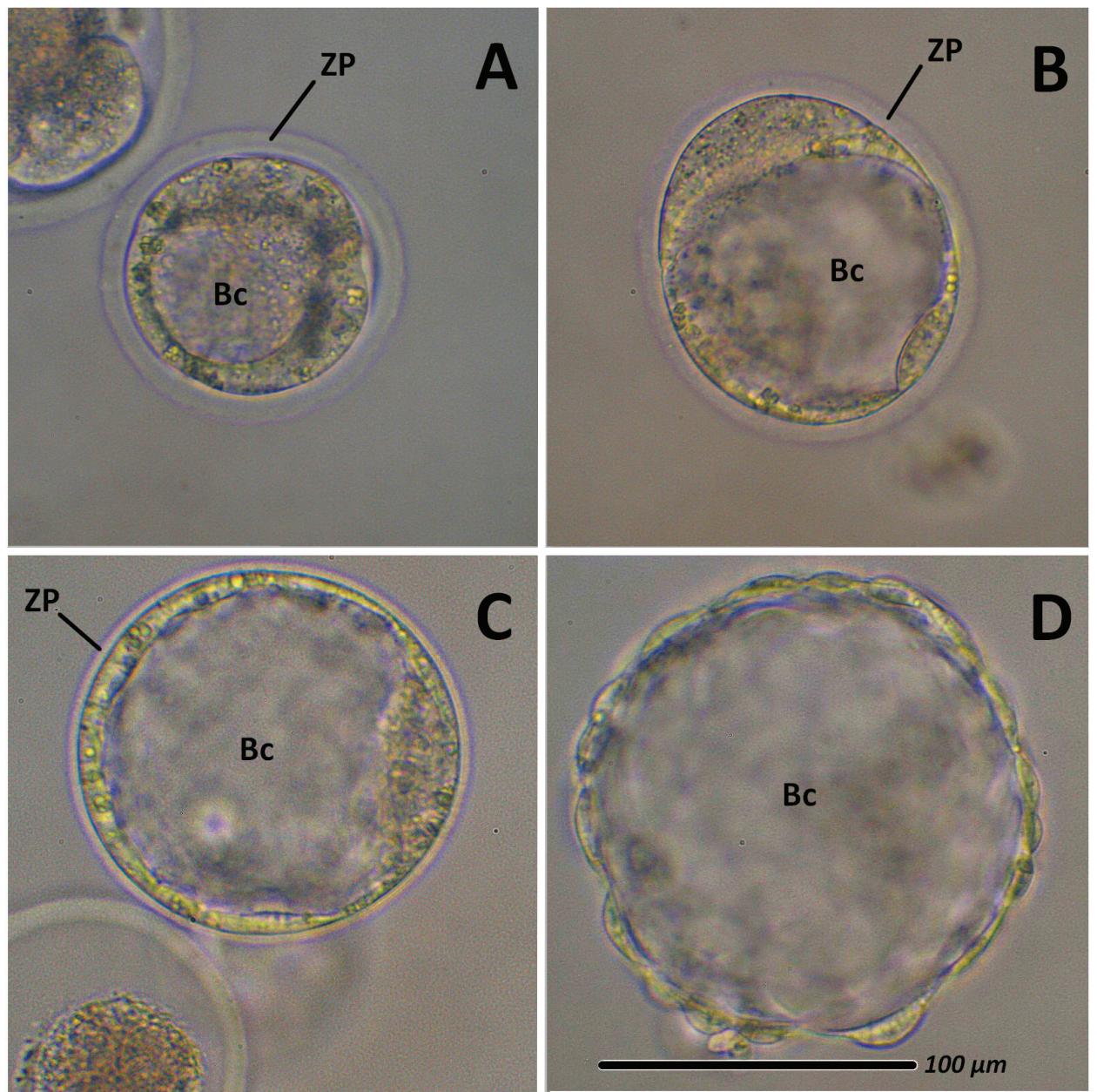

Fig. 5. Representative images of blastocysts showing diverse degrees of blastocoel expansion. $\mathrm{A}=$ early blastocyst (cultured in $1 \mathrm{ng} / \mathrm{ml} \mathrm{T}-2$ ); $\mathrm{B}=$ mid-blastocyst (cultured in $0.5 \mathrm{ng} / \mathrm{ml} \mathrm{T}-2$ ); $\mathrm{C}=$ expanded blastocyst (control) and $\mathrm{D}=$ hatched blastocyst (control).

Scale bar represents $100 \mu \mathrm{m} . \mathrm{Bc}=$ blastocoel; $\mathrm{ZP}=$ zona pellucida. Magnification: $\times 400$ 


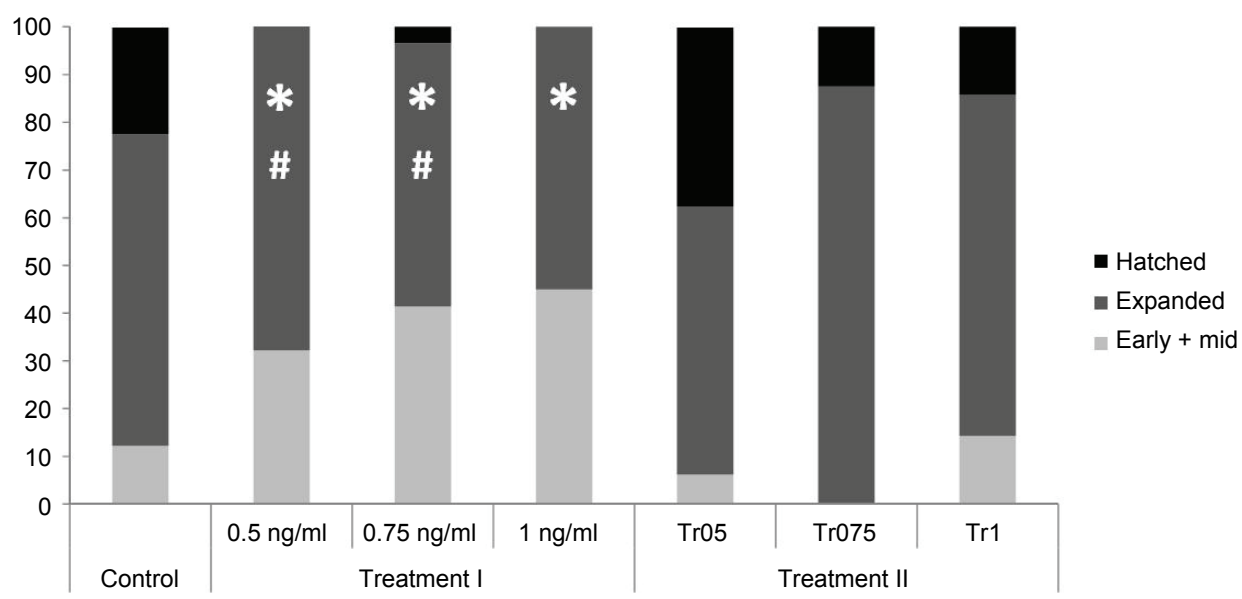

Fig. 6. Proportion of blastocysts being in different stages (early and mid-, expanded and hatched blastocyst stage) following $96 \mathrm{~h}$ in vitro culture. ${ }^{*} \mathrm{P}<0.05$ between rreatments and control; ${ }^{\#} \mathrm{P}<0.05$ between treatments I and II

Comparing the proportion of expanded/hatched blastocysts at equivalent toxin concentrations in treatments I and II, we found significant differences in the case of $0.5 \mathrm{ng} / \mathrm{ml}$ and $0.75 \mathrm{ng} / \mathrm{ml}$ toxin concentrations $(67.9 \%$ vs. $93.8 \%$ and $58.6 \%$ vs. $100 \%$, respectively). Although the rate of late blastocysts in the $1 \mathrm{ng} / \mathrm{ml}$ and $\operatorname{Tr} 1$ groups did not differ significantly $(\mathrm{P}=0.059)$, a clear tendency was found (55\% vs. $85.7 \%$, respectively).

\section{Discussion}

The T-2 toxin concentrations used in this experiment were $0.5,0.75$ and $1 \mathrm{ng} / \mathrm{ml}$. According to our previous studies (Somoskői et al., 2012, 2014), 0.75 and $1 \mathrm{ng} / \mathrm{ml} \mathrm{T}-2$ concentrations decreased the proportion of blastocysts, caused the formation of micronuclei and lobulated nuclei in the blastomeres; however, already a T-2 concentration of $0.5 \mathrm{ng} / \mathrm{ml}$ delayed blastocoel formation.

Our data show that T-2 mycotoxin affects preimplantation embryo development even at low concentrations. Although morulae and blastocysts exhibited normal morphology in a toxin-contaminated environment (treatment I: $0.5 \mathrm{ng} / \mathrm{ml}$, $0.75 \mathrm{ng} / \mathrm{ml}$ and $1 \mathrm{ng} / \mathrm{ml} \mathrm{T}-2$ ), these embryos had significantly fewer blastomeres (lower cell number) following both 72 and $96 \mathrm{~h}$ of culture than did the control embryos. Since the cell number of embryos indicates developmental capacity, it is a suitable marker of viability. Decreased blastomere number may result in reduced developmental ability (Zakhartchenko et al., 1995; Shapiro et al., 2000). Yuan et al. (2014) investigated the effect of T-2 on zebrafish embryos via $144 \mathrm{~h}$ of exposure. They found dose-dependent tail malformation and increased reac- 
tive oxygen species (ROS) production. However, the lowest effect level was found to be $93.3 \mathrm{ng} / \mathrm{ml}$. Our results indicate that the mouse embryo model is an effective and sensitive tool to evaluate the harmful effects of T-2 contamination in vitro.

The transfer of control embryos into contaminated media (treatment II) was found to have a remarkable effect. The cell number of these blastocysts (Tr05, Tr075 and $\operatorname{Tr} 1$ ) was significantly lower compared to the control ones. Although blastomere number was slightly higher in treatment II than in treatment I, the differences between these groups were not significant, except at $1 \mathrm{ng} / \mathrm{ml} \mathrm{con-}$ centration, however, with a weak significance $(\mathrm{P}=0.048)$ and a high SD.

Micronuclei are small fragments of chromatin separated from the main cell nucleus, which are evidence of chromosome breaking or mitotic spindle dysfunction and are frequently produced by genotoxic agents or other stress factors (e.g. cryostress) (Heddle et al., 1991; AbdelHafez, 2011). Jackson et al. (1998) found poor implantation potential associated with a high proportion of fragmented chromatin. Furthermore, micronuclei have been associated with developmental arrest (Moriwaki et al., 2004), defective S phase (Ye et al., 2003), disturbance in mitotic apparatus, as well as impaired topoisomerease II functioning (Tian and Yamanuchi, 2003) and apoptosis (Hnida et al., 2004). Our data show that the proportion of micronuclei in embryos cultured in toxin-containing media for $96 \mathrm{~h}$ remains at the same level as in the control embryos. This fact is in accordance with the observation that preimplantation embryos exhibit an amazing plasticity and tolerance when they come to adapting to the environment in which they are cultured (Lonergan et al., 2006). Experiences in assisted reproduction (particularly in cryopreservation) suggest that the stress tolerance of embryos increases with developmental stage (Martino et al., 2013). Although embryos in the $\operatorname{Tr} 1$ group did not show significantly higher micronucleus level (but a tendency was apparent), elevated micronucleus proportion was found in embryos transferred into media contaminated with 0.5 and $0.75 \mathrm{ng} / \mathrm{ml}$ toxin. These findings show that mouse embryos are sensitive to T-2 toxin even at advanced developmental stages.

Expansion of the blastocoel represents a developmental stage of the blastocyst (Dardik and Shultz, 1991) and the opportunity of implantation presents itself only in the receptive phase of the endometrium (implantation window) (Song et al., 2007). In mice, that implantation window is relatively narrow, about $24 \mathrm{~h}$, on day 4 (in vivo). Consequently, if the blastocyst is not in the late phase on day 4, the implantation will fail. Our results show that embryos cultured in a toxin-contaminated environment from the zygote stage (treatment I) reached the late blastocyst stage at a significantly lower rate than control ones and embryos in treatment II. Furthermore, no hatched blastocyst was found in a 0.5 and $1 \mathrm{ng} / \mathrm{ml}$ toxin-contaminated environment. 
Propidium iodide staining is a suitable method for detecting necrotic cells or those being in the late apoptotic phase. Although several studies show that T-2 can cause necrosis at extremely high concentrations $(475 \mathrm{ng} / \mathrm{ml})$ (Nasri et al., 2006), our data show that the concentrations we used induced necrosis at a negligible rate (mostly in less than $2 \%$ of blastomeres).

In conclusion, our data show that T-2 mycotoxin affects the developmental capacity and quality of preimplantation embryos. The effect may vary depending on the stage of the embryo when starting the exposure. At $96 \mathrm{~h}$ of exposure (from the zygote stage), the blastocysts have blastomeres with normal chromatin quality (same as the control ones) but their developmental potential is decreased. After $24 \mathrm{~h}$ of exposure applied following 72-h culture, blastomeres had a higher level of chromatin damage, although their developmental potential was the same as that of the control embryos. In both cases, we found a decreased mitotic rate, which resulted in a decreased blastomere number even at low T-2 toxin concentrations.

\section{Acknowledgement}

This work was supported by the Hungarian Scientific Research Fund (OTKA100810).

\section{References}

AbdelHafez, F., Xu, J., Goldberg, J. and Desai, N. (2011): Vitrification in open and closed carriers at different cell stages: assessment of embryo survival, development, DNA integrity and stability during vapor phase storage for transport. BMC Biotechnol. 11, 1-10.

Bennett, J. and Klich, M. (2003): Mycotoxins. Clin. Microbiol. Rev. 16, 497-516.

Beyer, M., Ferse, I., Mulac, D., Würthwein, E. and Humpf, H. (2009): Structural elucidation of T-2 toxin thermal degradation products and investigations toward their occurrence in retail food. J. Agric. Food Chem. 575, 1867-1875.

Biomin Holding GmbH (2015): Biomin Global Mycotoxin Survey 2015. https://info.biomin.net/ acton/fs/blocks/showLandingPage/a/14109/p/p-004e/t/page/fm/17

Caloni, F., Ranzenigo, G., Cremonesi, F. and Spicer, L. J. (2009): Effects of a trichothecene, T-2 toxin, on proliferation and steroid production by porcine granulosa cells. Toxicon $\mathbf{5 4}$, $337-344$.

Dardik, A. and Shultz, R. (1991): Blastocoel expansion in the preimplantation mouse embryo: stimulatory effect of TGF-alpha and EGF. Development 113, 919-930.

Glenn, A. E. (2007): Mycotoxigenic Fusarium species in animal feed. Anim. Feed Sci. Technol. 137, 213-240.

Heddle, J., Cimino, M., Hayashi, M., Romagna, F., Shelby, M. D., Tucker, J. D., Vanparys, P. and MacGregor, J. T. (1991): Micronuclei as an index of cytogenetic damage: past, present and future. Environ. Mol. Mutagen. 18, 277-291.

Hnida, C., Engenheiro, E. and Ziebe, S. (2004): Computer-controlled, multilevel, morphometric analysis of blastomere size as biomarker of fragmentation and multinuclearity in human embryos. Hum. Reprod. 19, 288-293. 
Huszenicza, Gy., Fekete, S., Szigeti, G., Kulcsár, M., Fébel, H., Kellems, R. O., Nagy, P., Cseh, S., Veresegyházy, T. and Hullár, I. (2000): Ovarian consequences of low dose peroral Fusarium (T-2) toxin in a ewe and heifer model. Theriogenology 53, 1631-1639.

Jackson, K., Ginsburg, E., Hornstein, M., Rein, M. and Clarke, R. (1998): Multinucleation in normally fertilized embryos is associated with an accelerated ovulation induction response and lower implantation and pregnancy rates in in vitro fertilization-embryo transfer cycles. Fertil. Steril. 70, 60-66.

Kovács, M., Tornyos, G., Matics, Z., Kametler, L., Rajli, V., Bodnár, Z., Kulcsár, M., Huszenicza, G., Keresztes, Z. and Cseh, S. (2011): Subsequent effect of subacute T-2 toxicosis on spermatozoa, seminal plasma and testosterone production in rabbits. Animal 5, 1563-1569.

Lonergan, P., Fair, T., Corcoran, D. and Evans, A. (2006): Effect of culture environment on gene expression and developmental characteristics in IVF-derived embryos. Theriogenology $\mathbf{6 5}$, $137-152$.

Martino, N., Dell'Aquila, M., Cardone, R., Somoskoi, B., Lacalandra, G. and Cseh, S. (2013): Vitrification preserves chromatin integrity, bioenergy potential and oxidative parameters in mouse embryos. Reprod. Biol. Endocrinol. 11, 27-38.

Moriwaki, T., Suganuma, N., Hayakawa, M., Hibi, H., Katsumata, Y., Oguchi, H. and Furuhashi, M. (2004): Embryo evaluation by analysing blastomere nuclei. Hum. Reprod. 19, 152-156.

Nasri, T., Bosch, R., Voorde, S. and Fink-Gremmels, J. (2006): Differential induction of apoptosis by type A and B trichothecenes in Jurkat T-lymphocytes. Toxicol. in Vitro 20, 832-840.

Saiz, N. and Plusa, B. (2013): Early cell fate decisions in the mouse embryos. Reproduction 145, 65-80.

Shapiro, B., Harris, D. and Richter, K. (2000): Predictive value of 72-hour blastomere cell number on blastocyst development and success of subsequent transfer based on the degree of blastocyst development. Fertil. Steril. 73, 582-586.

Somoskői, B., Keresztes, Z., Solti, L., Kovács, M. and Cseh, S. (2012): Effect of T-2 mycotoxin on early development of mouse embryos [in Hungarian, with English abstract]. Magy. Allatorvosok 10, 614-619.

Somoskői, B., Kovács, M. and Cseh, S. (2014): Effects of T-2 mycotoxin on in vitro development and chromatin status of mouse embryos being in preimplantation stages. Toxicol. Ind. Health doi:10.1177/0748233714555394.

Song, H., Han, K. and Lim, H. (2007): Progesterone supplementation extends uterine receptivity for blastocyst implantation in mice. Reproduction 133, 487-493.

Tian, Y. and Yamanuchi, T. (2003): Micronucleus formation in 3-day mouse embryos associated with maternal exposure to chlorpyrifos during the early preimplantation period. Repr. Tox. 17, 401-405.

Ványi, A., Glávits, R. and Molnár, T. (1995): Reproductive disorders due to F-2 and T-2 toxins in large-scale pig farms [in Hungarian, with English abstract]. Magy. Allatorvosok 50, 424-430.

Weidner, M., Hüwel, S., Ebert, F., Schwerdtle, T., Galla, H. and Humpf, H. (2013): Influence of T2 and HT-2 toxin on the blood-brain barrier in vitro: new experimental hints for neurotoxic effects. PLoS One 8, e60484.

Ye, X., Franco, A., Santos, H., Nelson, D., Kaufman, P. and Adams, P. (2003): Defective S phase chromatin assembly causes DNA damage, activation of the $\mathrm{S}$ phase checkpoint, and $\mathrm{S}$ phase arrest. Mol. Cell 11, 341-351.

Yuan, G., Wang, Y., Yuan, X., Zhang, T., Zhao, J., Huang, L. and Peng, S. (2014): T-2 induces developmental toxicity and apoptosis in zebrafish embryos. J. Environ. Sci. 26, 917-925.

Zakhartchenko, V., Wolf, E., Palma, G. and Brem, G. (1995): Effect of donor embryo cell number and cell size on the efficiency of bovine embryo cloning. Mol. Reprod. Dev. 42, 53-57. 